\title{
Potential attack of the common vampire bat (Desmodus rotundus) on nine-banded armadillo (Dasypus novemcinctus) in northern Oaxaca, México
}

\section{Ataque potencial del vampiro común (Desmodus rotundus) a un armadillo de nueve bandas (Dasypus novemcinctus) en el norte de Oaxaca, México}

\author{
Jesús Alejandro Ríos-Solís ${ }^{1}$, Juan Carlos López-Acosta ${ }^{1}$, and M. Cristina MacSwiney G. ${ }^{1 *}$ \\ ${ }^{1}$ Centro de Investigaciones Tropicales, Universidad Veracruzana. Calle José María Morelos y Pavón 44, Centro, C. P. 91000. Xalapa, \\ Veracruz, México. E-mail: biol-alex@hotmail.com (JAR-S); carlolopez@uv.mx (JCL-A); cmacswiney@uv.mx (MCMG). \\ *Corresponding author
}

\begin{abstract}
The common vampire bat, Desmodus rotundus, is considered a predator and an obligate feeder on vertebrate blood of a diverse group of prey, but with preference to both native and exotic mammals. The present record is the first documented potential predation of a nine-banded armadillo, Dasypus novemcinctus, by D. rotundus in the wild. The observation was recorded on a camera trap set in a secondary growth fragment of tropical evergreen forest in Oaxaca, México. In a 10 second recording, we observed an individual of $D$. rotundus stalking and chasing an individual $D$. novemcinctus that is searching for food in the leaf litter. The present observation along with another study carried out in Brazil, where a vampire bat chased a giant armadillo Priodontes maximus, suggest that armadillos might be prey of $D$. rotundus, but the interaction is difficult to document in the wild.
\end{abstract}

Key words: Chiroptera; ecological interaction; predation; sanguivorous bat; southern México.

El murciélago vampiro común, Desmodus rotundus, es un depredador que de forma obligatoria, se alimenta de sangre de vertebrados de un grupo diverso de presas, pero con preferencia a los mamíferos, tanto nativos como exóticos. El presente registro documenta la primera depredación potencial de un armadillo de nueve bandas, Dasypus novemcinctus, por D. rotundus en vida silvestre. La observación se registró en una cámara trampa colocada en un fragmento de crecimiento secundario de un bosque tropical perennifolio en Oaxaca, México. En una grabación de 10 segundos, observamos a un individuo de $D$. rotundus acechando y persiguiendo a un individuo de $D$. novemcinctus que busca alimento en la hojarasca. La presente observación, junto con otro estudio realizado en Brasil, donde un murciélago vampiro persiguió a un armadillo gigante Priodontes maximus, sugiere que los armadillos podrían ser presas de $D$. rotundus, pero la interacción es difícil de registrar en vida silvestre.

Palabras clave: Chiroptera; depredación; interacción ecológica; murciélago sanguívoro; sur de México.

(C) 2021 Asociación Mexicana de Mastozoología, www.mastozoologiamexicana.org

The three vampire bat species are distributed in México (Medellín et al. 2008), being the common vampire bat, Desmodus rotundus, the most widespread and abundant one. This species is distributed from Sonora and Tamaulipas, México, through Central and South America to the north of Chile and north of Argentina (Reid 2009). Desmodus rotundus inhabits a wide range of vegetation types including mature forest, secondary growth, several crops, and pasturelands (Coates-Estrada and Estrada 1986); it occurs from sea level to over 3,500 m (Martins et al. 2009), but its distribution is limited to areas warmer than the $10^{\circ} \mathrm{C}$ isotherm in January because of the animal's poor capacity to thermoregulate (McNab 1973).

The common vampire bat is considered a predator and an obligate blood-feeding mammal, feeding on a diverse group of vertebrates, but with preference to mammals
(Reid 2009). It has been documented that it can feed on several breeds of livestock such as cows, sheeps, pigs, goats, horses, mules, and poultry (Greenhall 1988; Delpietro et al. 1992; Bobrowiec et al. 2015), and that it has a strong preference of these over native species, at least in areas under strong human influence (Voigt and Kelm 2006). It also preys on several species of reptiles and birds (Carter et al. 2021).

The common vampire bat shows terrestrial locomotion that allows it to sneak up on its prey to feed and to be able to escape if some danger threatens it (Riskin et al. 2006). Vampire bats are agile predators that are rarely seen in the wild. However, the use of camera traps in the last years has provided insights about its feeding behavior both in native and exotic species. For example, recent studies have shown predation upon the South American 
tapir Tapirus terrestris (Gnocchi and Srbek-Araujo 2017), the capybara Hydrochoerus hydrochaeris (Gonçalves et al. 2020), the collared peccary Pecari tajacu (Zortéa et al. 2018), the exotic wild pig Sus scrofa (Hernández-Pérez et al. 2019), among others. In the present study, we report the possible predation event of a common vampire bat $D$. rotundus on a nine-banded armadillo, Dasypus novemcinctus.

The interaction between the common vampire bat, $D$. rotundus, and the armadillo, $D$. novemcinctus, was registered on a camera trap Cuddeback Model E3 on December $5^{\text {th }} 2015$, at 20:26 hr in the locality of San Cristóbal La Vega, the municipality of San Juan Bautista Valle Nacional, Oaxaca, México. The camera trap was set at the coordinates $17^{\circ}$ $46^{\prime} 8.01^{\prime \prime} \mathrm{N}, 96^{\circ} 15^{\prime} 6.47^{\prime \prime} \mathrm{W}$, in a secondary growth fragment of tropical evergreen forest.

In a 10-second recording, we observed an individual of $D$. rotundus stalking and chasing an individual of $D$. novemcinctus that is searching for food in the leaf litter its forefeet and snout. The individual of $D$. rotundus landed in the proximity of the armadillo, in the following seconds the armadillo moved out of the camera frame, and we observed the vampire moving the head and emitting calls, probably to locate the armadillo and after this, it flew away in the same direction of the armadillo (Figure 1 A-D; Appendix 1).

In the past 10 ten years, photographs and videos taken with camera traps have shown $D$. rotundus feeding on a variety of species in the wild, including wild feral pigs and collared peccaries, lowland tapirs, red brocket deer, whitetailed deer, chital deer, orange breasted falcon, tamandua, giant armadillo and a mountain lion (reviewed by Carter et al. 2021). The present record is the first documented potential attack of an armadillo by $D$. rotundus in the wild, based on the behavior displayed by $D$. rotundus, that usually lands close to a potential prey and chase this until find a vulnerable part of the body to bite (Zortéa et al. 2018). There is only one previous record of the interaction between $D$. rotundus and $D$. novemcinctus, but it took place in captivity. Greenhall (1988) conducted behavioral studies in the laboratory and observed an individual of $D$. rotundus feeding on the captive $D$. novemcinctus. In this study, $D$. rotundus bit the armadillo in the tail between the scutes and on a foot, with no defensive reaction from the prey.

In a recent study carried out in Brazil, the authors recorded a vampire bat chasing another species of armadillo, the giant armadillo Priodontes maximus, in a similar fashion as the observation recorded in the present study (Zortéa et al. 2018). These observations suggest that armadillos might be the prey of $D$. rotundus, but the interaction is difficult to document and needs to be confirmed in the wild. In the following years, with the increasing use of camera traps, we might be able to record more interaction events between these two species.
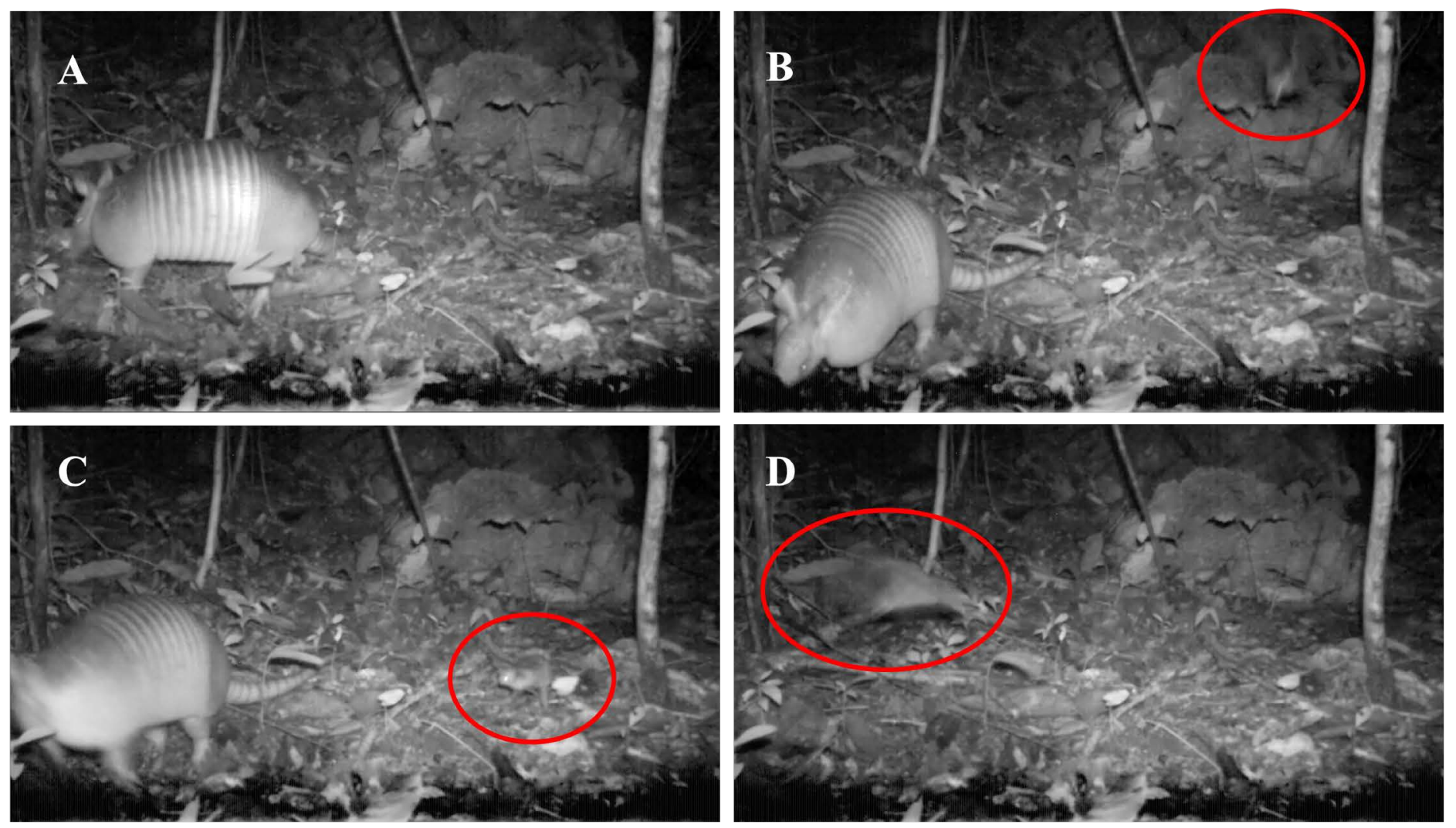

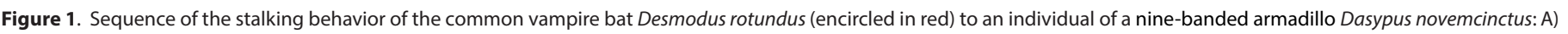

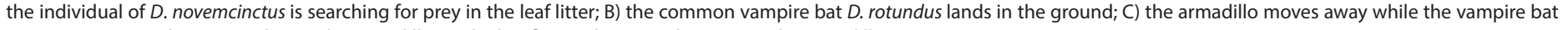
seems to emit vocalizations to locate the armadillo; D) the bat flies in the same direction to the armadillo. 


\section{Acknowledgements}

The first author thanks Comisión Nacional de Areas Naturales Protegidas (CONANP) for the funding of the project PROCER/RFSIPS/15/2015 and Consejo Nacional de Ciencia y Tecnología for the scholarship (\#463734) awarded for his master's studies. We thank the partial financial support provided by the Centro de Investigaciones Tropicales, Universidad Veracruzana, and we also thank the authorities of the ejido of San Cristóbal La Vega, municipio de San Juan Bautista Valle Nacional, Oaxaca, México. We thank the two anonymous reviewers whose comments improved earlier versions of this manuscript.

\section{Literature cited}

Bobrowiec, P. E. D., M. R. Lemes, and R. Gribel. 2015. Prey preference of the common vampire bat (Desmodus rotundus, Chiroptera) using molecular analysis. Journal of Mammalogy 96:54-63.

Carter, G., B. Brown, I. Razik, and S. Ripperger. 2021. Penguins, falcons, and mountain lions: The extraordinary host diversity of vampire bats. Pp. 151-170 in 50 Years of bat research Foundations and New Frontiers (Lim, B. K., M. B. Fenton, R. M. Brigham, S. Mistry, A. Kurta, E. H. Gillam, A. Russell, and J. Ortega, eds.). Springer Nature. Cham, Switzerland.

Coates-Estrada, R., and A. Estrada. 1986. Manual de identificación de campo de los mamíferos de la Estación de Biología "Los Tuxtlas." Universidad Nacional Autónoma de México. México City, México.

Delpietro, H. A., N. Marchevsky, and E. Simonetti. 1992. Relative population densities and predation of the common vampire bat (Desmodus rotundus) in natural and cattle-raising areas in north-east Argentina. Preventive Veterinary Medicine 14:13-20.

Gnocchi, A. P., and A. C. Srbek-Araujo. 2017. Common vampire Bat (Desmodus rotundus) feeding on Lowland Tapir (Tapirus terrestris) in an Atlantic Forest remnant in southeastern Brazil. Biota Neotropica 17:e20170326.

Gonçalves, F., M. Magiolı, R. S. BovendorP, K. M. P. M. de BarrosFerraz, L. Bulascoschi-Cagnoni, M. Z. Moreira, and M. Galetti. 2020. Prey choice of introduced species by the common vampire bat (Desmodus rotundus) on an Atlantic Forest LandBridge Island. Acta Chiropterologica 22:167-174.

Greenhall, A. M. 1988. Feeding behavior. Pp. 111-131 in Natural history of vampire bats (Greenhall, A. M., and U. Schmidt, eds.). CRC Press. Boca Ratón, Florida, U.S.A.

Hernández-Pérez, E. L., G. Castillo-Vela, G. García-Marmolejo, M. Sanvicente-López, and R. Reyna-Hurtado. 2019. Wild pig (Sus scrofa) as prey of the common vampire bat (Desmodus rotundus). Therya 10:195-199.

Martins, F. M., A. R. Templeton, A. C. Pavan, B. C. Kohlbach, and J. S. Morgante. 2009. Phylogeography of the common vampire bat (Desmodus rotundus): marked population structure, Neotropical Pleistocene vicariance and incongruence between nuclear and mtDNA markers. BMC Evolutionary Biology 9:294.

McNAB, B. 1973. Energetics and the distribution of vampires. Journal of Mammalogy 54:131-144.
Medellín, R., H. Arita, and O. Sánchez. 2008. Identificación de los murciélagos de México. Clave de campo. 2d. Ed. Instituto de Ecología, Universidad Nacional Autónoma de México. México City, México.

REID, F. 2009. A Field Guide to the Mammals of Central America and Southeast Mexico. 2d. Ed. Oxford University Press. New York, U.S.A.

Riskin, D. K., S. Parsons, W. A. Schutt, G. G. Carter, and J. W. Hermanson. 2006. Terrestrial locomotion of the New Zealand short-tailed bat Mystacina tuberculata and the common vampire bat Desmodus rotundus. Journal of Experimental Biology 209:1725-1736.

Voigt, C. C., AND D. H. KeLm. 2006. Host preference of the common vampire bat (Desmodus rotundus; Chiroptera) assessed by stable isotopes. Journal of Mammalogy 87:1-6.

Zortéa, M. D. A. Silva, and A. M. CalaçA. 2018. Susceptibility of targets to the vampire bat Desmodus rotundus are proportional to their abundance in Atlantic Forest fragments? Iheringia, Série Zoologia 108:e2018037.

Associated editor: Jesús R. Hernández-Montero

Submitted: June 22, 2021; Reviewed: August 21, 2021.

Accepted: October 11, 2021; Published on line: November 1, 2021. 


\section{Appendix 1}

Video of the interaction between a nine-banded armadillo Dasypus novemcinctus and the common vampire bat Desmodus rotundus, recorded in a secondary forest fragment of evergreen forest in Oaxaca, México.

Video hosted in: http://doi.org/10.5281/zenodo.5007162 